\title{
Paraprevotella clara gen. nov., sp. nov. and Paraprevotella xylaniphila sp. nov., members of the family 'Prevotellaceae' isolated from human faeces
}

Correspondence

Masami Morotomi

masami-morotomi@yakult.co.jp

\author{
Masami Morotomi, Fumiko Nagai, Hiroshi Sakon and Ryuichiro Tanaka \\ Yakult Central Institute for Microbiological Research, 1796 Yaho, Kunitachi, Tokyo 186-8650, \\ Japan
}

\begin{abstract}
Two anaerobic, non-spore-forming, pleomorphic, Gram-negative rods, designated YIT $11840^{\top}$ and YIT $11841^{\top}$, were isolated from human faeces. The organisms were catalase-negative, produced succinic and acetic acids as end products of glucose metabolism and had DNA G +C contents of approximately 48-49 mol\%. Although the phenotypic characteristics of these two strains were very similar, analysis of their 16S rRNA gene sequences showed that they are only distantly related (93.8\%), indicating that they represent two different species. A comparative sequence analysis revealed that these two species are members of the family 'Prevotellaceae' but are phylogenetically distant ( $<88 \%$ sequence similarity) from the known genera belonging to this family, including Prevotella, Hallela and Xylanibacter. On the basis of the phylogenetic analysis and physiological tests, strains YIT $11840^{\top}$ and YIT $11841^{\top}$ represent two novel species of a new genus, for which the names Paraprevotella clara gen. nov., sp. nov. (type strain YIT $11840^{\top}=\mathrm{JCM}$ $14859^{\top}=\mathrm{DSM} 19731^{\top}$ ), the type species, and Paraprevotella xylaniphila sp. nov. (type strain YIT $11841^{\top}=$ JCM $14860^{\top}=$ DSM $19681^{\top}$ ) are proposed.
\end{abstract}

Comparative $16 \mathrm{~S}$ rRNA gene sequence analysis has revealed that the large intestine in humans harbours up to $10^{14}$ bacteria, comprising more than 500 species (reviewed by Rajilić-Stojanović et al., 2007). Most of these organisms are members of the phyla Firmicutes and Bacteroidetes (Eckburg et al., 2005; Hayashi et al., 2002; Wang et al., 2003). Species belonging to the families Bacteroidaceae, 'Prevotellaceae', 'Porphyromonadaceae' and 'Rikenellaceae' of the order 'Bacteroidales' are common members of the human intestinal and oral microbiota, whereas more than $70 \%$ of the human intestinal 'Bacteroidales' phylotypes reported are detected only in cultivation-independent studies (Rajilić-Stojanović et al., 2007). This observation can be attributed (at least to some extent) to the lack of appropriate cultivation techniques and to incomplete cultivation efforts.

To clarify the physiological characteristics and functions of the majority of the members of the human gastrointestinal microbiota, we have performed several intensive cultivation trials aimed at isolating so-called 'unculturable' or 'asyet-uncultured' bacteria from the human gastrointestinal tract (Sakon et al., 2008; Morotomi et al., 2008; Nagai et al., 2009). In this article, we report the isolation of two novel members of the family 'Prevotellaceae' isolated from

The GenBank/EMBL/DDBJ accession numbers for the 16S rRNA gene sequences of strains YIT $11840^{\top}$ and YIT $11841^{\top}$ are AB331896 and AB331897. human faeces. Although we propose novel taxonomic units (genus and species) based on a single isolate, these isolates displayed $>98 \% \quad 16 \mathrm{~S}$ rRNA gene sequence similarity to some of the human intestinal uncultured clones reported by several groups in the USA and other countries, as described below, indicating that these bacteria are common members of the human intestinal microbiota.

Faecal samples were collected from two healthy Japanese males (subjects A and B; aged 54 and 38 years, respectively) and immediately transferred anaerobically. Initial processing and subsequent weighing and dilution of the specimens were carried out under strictly anaerobic conditions by using a modification of the Hungate technique (Holdeman et al., 1977). Each sample was weighed and diluted with pre-reduced $0.1 \mathrm{M}$ PBS (pH 7). Diluted samples were spread onto modified Gifu medium (GAM; Nissui Pharmaceutical) containing agar and supplemented with a mixture of antibiotics (described below) to isolate subdominant groups in the intestinal microbiota. Plates were incubated at $37{ }^{\circ} \mathrm{C}$ for 3 days in an anaerobic glove box (Coy Laboratory Products) containing $\mathrm{N}_{2} / \mathrm{H}_{2} / \mathrm{CO}_{2}$ $(88: 7: 5)$. The composition of the modified GAM agar was described in our previous report (Sakon et al., 2008). Strain YIT $11840^{\mathrm{T}}$ was isolated from a GAM agar plate supplemented with trimethoprim $\left(32 \mu \mathrm{g} \mathrm{ml}^{-1}\right)$, streptomycin sulfate $\left(16 \mu \mathrm{g} \mathrm{ml}^{-1}\right)$ and vancomycin hydrochloride $\left(2 \mu \mathrm{g} \mathrm{ml}^{-1}\right)$ and then inoculated with a $10^{-6}$ serially diluted faecal sample from subject A. Strain YIT 
$11841^{\mathrm{T}}$ was isolated from a GAM agar plate supplemented with trimethoprim $\left(32 \mu \mathrm{g} \mathrm{ml}^{-1}\right)$, streptomycin sulfate $\left(16 \mu \mathrm{g} \mathrm{ml}^{-1}\right)$, vancomycin hydrochloride $\left(0.5 \mu \mathrm{g} \mathrm{ml}^{-1}\right)$ and erythromycin $\left(0.25 \mu \mathrm{g} \mathrm{ml}^{-1}\right)$ and then inoculated with a $10^{-6}$ serially diluted faecal sample from subject B. All of these antibiotics were obtained from Sigma-Aldrich. Single colonies were picked and streaked on the modified GAM agar until single cultures were obtained.

The end products of bacterial metabolism of glucose and xylan, in pre-reduced peptone/yeast extract medium (Holdeman et al., 1977) supplemented with $1 \%$ glucose or $1 \%$ birch-wood xylan (Sigma), respectively, were analysed using HPLC according to a previously described procedure (Chonan et al., 1995). Cellular morphology was determined after Gram-staining of 3-day plates. Bile resistance was tested by growing the bacteria on GAM agar plates supplemented with $2 \%$ Bacto oxgall (Difco). Biochemical characteristics were determined using the API Rapid ID 32A, API ZYM and API 20A systems (bioMérieux) according to the manufacturer's instructions. Fatty acid methyl esters were obtained from lyophilized cells by saponification, methylation and extraction, using the method of Miller (1982) but with minor modifications (Kuykendall et al., 1988). Fatty acid methyl esters were determined with a Shimadzu gas chromatograph (model GC-14A) and a Shimadzu chromatograph-data processor (model C-R5A). Fatty acid methyl ester peaks were identified with a bacterial acid methyl ester mix (Supelco) by using retention-time comparisons against standard compounds. Isoprenoid quinones were extracted as described by Komagata \& Suzuki (1987) and were analysed by means of an HPLC-atmospheric pressure chemical ionization-MS/MS system (API3200; Applied Biosystems) with an L-column ODS $(2.1 \times 150 \mathrm{~mm}$; Chemicals Evaluation and Research Institute, Japan), using the modified method of Katsuta et al. (2005). The G+C content was determined by hydrolysing the DNA enzymically and quantifying the nucleosides by means of HPLC according to the method of Ezaki et al. (1990).

Closely related sequences were retrieved from the DNA Data Bank of Japan by using the program FASTA (Pearson \& Lipman, 1985). The sequences were aligned and used to produce an unrooted phylogenetic tree with the neighbour-joining method (Saitou \& Nei, 1987), using CLUSTAL_X (version 1.83) (Thompson et al., 1997). The stability of the groups was estimated by means of bootstrap analysis (1000 replications) in CLUSTAL_X. The trees were visualized by using the program TreeView (version 1.6.6) (Page, 1996). The minimum-evolution method (1000 bootstrap replicates) in MEGA4 (Tamura et al., 2007) and the maximum-likelihood method from the PHYLIP program package (Felsenstein, 1993) were used to confirm the phylogenetic placement of the aligned sequences. $16 \mathrm{~S}$ rRNA gene sequence similarities between YIT $11840^{\mathrm{T}}$ and YIT $11841^{\mathrm{T}}$ and between these strains and the type strains of all described species within the family 'Prevotellaceae' were calculated using FASTA (Pearson \& Lipman, 1985) and EzTaxon (Chun et al., 2007).
The physiological characteristics of strains YIT $11840^{\mathrm{T}}$ and YIT $11841^{\mathrm{T}}$ were very similar, except for the production of acid from maltose (YIT $11840^{\mathrm{T}}$, weakly positive; YIT $11841^{\mathrm{T}}$, negative) and from D-xylose (YIT $11840^{\mathrm{T}}$, positive; YIT $11841^{\mathrm{T}}$, weakly positive). The cells were Gram-negative, obligately anaerobic, non-motile, pleomorphic coccobacilli (YIT $11840^{\mathrm{T}}, \quad 0.4-1.3 \times 0.7-2.2 \mu \mathrm{m} ;$ YIT $11841^{\mathrm{T}}, \quad 0.4-$ $1.5 \times 0.9-2.2 \mu \mathrm{m})$ that occurred singly, in pairs and in short chains. After 3 days of anaerobic incubation on GAM agar, colonies were $1.5-4.0 \mathrm{~mm}$ (YIT $11840^{\mathrm{T}}$ ) or $0.3-1.0 \mathrm{~mm}$ (YIT $\left.11841^{\mathrm{T}}\right)$ in diameter, entire, shiny and translucent with irregular or round margins. Growth of these strains in peptone/yeast extract/glucose broth was weak; small amounts of succinate and acetate were detected as end products of metabolism. However, growth of these strains was stimulated by xylan: large amounts of succinate (YIT $11840^{\mathrm{T}}, 6.7 \mathrm{mM}$; YIT $11841^{\mathrm{T}}, 18.3 \mathrm{mM}$ ) and acetate (YIT $11840^{\mathrm{T}}, 7.0 \mathrm{mM}$; YIT $11841^{\mathrm{T}}, 13.2 \mathrm{mM}$ ) were detected after incubation in peptone/yeast extract/xylan broth. Biochemical characteristics determined using the API Rapid ID 32A, API ZYM and API 20A systems are described in Table 1.

The chemotaxonomic characteristics of strains YIT $11840^{\mathrm{T}}$ and YIT $11841^{\mathrm{T}}$ were very similar. The major cellular fatty acids were anteiso- $\mathrm{C}_{15: 0}$ (33.0 and $21.8 \%$, respectively, in strains YIT $11840^{\mathrm{T}}$ and YIT $\left.11841^{\mathrm{T}}\right)$, iso- $\mathrm{C}_{15: 0}(17.0$ and $17.3 \%)$ and $\mathrm{C}_{18: 1} \omega 9 c(20.8$ and $38.0 \%)$. The following other fatty acids were detected: $\mathrm{C}_{14: 0}(5.4$ and $2.6 \%), \mathrm{C}_{15: 0}$ (8.5 and $2.4 \%), \mathrm{C}_{16: 0}(2.2$ and $2.4 \%), \mathrm{C}_{18: 2} \omega 9,12 c(1.1$ and $1.2 \%), \mathrm{C}_{18: 1} \omega 9 t(0.8$ and $1.8 \%)$ and unknown fatty acids (11.3 and $12.5 \%$; peaks with equivalent chain-lengths of 13.6 and 17.3 in both strains and 16.3 in YIT $11840^{\mathrm{T}}$ or 22.2 in YIT $11841^{\mathrm{T}}$ ). For both strains, the major respiratory quinones were MK-10 $\left(\mathrm{H}_{0}\right)$ and MK-11 $\left(\mathrm{H}_{0}\right)$ (Table 1). Although the predominant menaquinones of strains YIT $11840^{\mathrm{T}}$ and YIT $11841^{\mathrm{T}}$ were similar to those of Prevotella melaninogenica and Prevotella veroralis, the overall pattern of the cellular fatty acid content and the other biological and biochemical characteristics differed from those of phylogenetically related, phenotypically similar Prevotella species of human oral and intestinal origin (Table 1).

Approximately $1500 \mathrm{bp}$ of the 16S rRNA genes of YIT $11840^{\mathrm{T}}$ and YIT $11841^{\mathrm{T}}$ were sequenced. Although YIT $11840^{\mathrm{T}}$ and YIT $11841^{\mathrm{T}}$ had very similar phenotypic characteristics, comparison of their partial 16S rRNA gene sequences revealed that these strains were only distantly related (93.8\% sequence similarity) and therefore (on the basis of the phylogenetic species concept) represented two different species. In database searches, the highest levels of similarity were found with respect to Prevotella species (YIT $11840^{\mathrm{T}}, 88.5-84.9 \%$; YIT $11841^{\mathrm{T}}, 88.6-84.6 \%$ ). A phylogenetic analysis of these and other related sequences was performed: it confirmed that strains YIT $11840^{\mathrm{T}}$ and YIT $11841^{\mathrm{T}}$ were phylogenetically most closely associated with members of the 'Prevotellaceae' (species belonging to the genera Prevotella, Hallela and Xylanibacter) but formed a separate cluster (Fig. 1). In contrast, the $16 \mathrm{~S}$ rRNA gene sequences most similar to those of YIT $11840^{\mathrm{T}}$ (98.9- 
Table 1. Differential characteristics of strains YIT $11840^{\top}$ and YIT $11841^{\top}$ and strains of phylogenetically related, phenotypically similar Prevotella species of human oral and intestinal origin

Strains: 1, YIT $11840^{\mathrm{T}}$; 2, YIT $11841^{\mathrm{T}} ; 3$, P. copri (data for five strains, including the type strain); 4, P. stercorea JCM $13469^{\mathrm{T}} ; 5$, P. loescheii JCM 8530 ${ }^{\mathrm{T}}$; 6, P. marshii JCM $13450^{\mathrm{T}} ; 7$, P. melaninogenica JCM $6325^{\mathrm{T}} ; 8$, P. oralis JCM $12251^{\mathrm{T}} ; 9$, P. salivae JCM $12084^{\mathrm{T}} ; 10$, P. shahii JCM $12083^{\mathrm{T}} ; 11$, P. veroralis JCM $6290^{\mathrm{T}}$. Data for reference strains were obtained from Hayashi et al. (2007) unless indicated otherwise. +, Positive; -, negative; v, variable; w, weak; ai-, anteiso-branched; i-, iso-branched; ND, no data. All strains are positive for acid production from D-glucose, but negative for acid production from D-mannitol, glycerol, D-sorbitol and trehalose. All strains are positive for acid phosphatase, negative for esterase (C4), lipase (C4), leucine, valine and cystine arylamidases, trypsin and $\beta$-glucuronidase activities. All strains are negative for indole formation and for urease and catalase activities.

\begin{tabular}{|c|c|c|c|c|c|c|c|c|c|c|c|}
\hline Characteristic & 1 & 2 & 3 & 4 & 5 & 6 & 7 & 8 & 9 & 10 & 11 \\
\hline Aesculin hydrolysis & - & - & + & - & + & - & - & + & + & - & + \\
\hline Gelatin hydrolysis & - & - & - & - & + & + & + & - & - & - & - \\
\hline \multicolumn{12}{|l|}{ Acid production from: } \\
\hline L-Arabinose & + & + & + & - & - & - & - & - & + & - & - \\
\hline Cellobiose & - & - & + & - & - & - & - & + & + & - & + \\
\hline Lactose & - & - & + & + & + & - & + & + & + & + & + \\
\hline Maltose & $\mathrm{w}$ & - & + & + & + & + & + & + & + & + & + \\
\hline D-Mannose & + & + & - & + & + & + & + & + & + & + & + \\
\hline Melezitose & - & - & $\mathrm{V}$ & - & - & - & - & - & - & - & - \\
\hline Raffinose & - & - & + & + & + & + & + & + & + & + & + \\
\hline L-Rhamnose & - & - & + & - & - & - & - & - & - & - & - \\
\hline Salicin & - & - & + & - & - & - & - & - & + & - & - \\
\hline Sucrose & - & - & + & + & + & - & + & + & + & + & + \\
\hline D-Xylose & + & $\mathrm{w}$ & + & - & - & - & - & - & + & - & - \\
\hline \multicolumn{12}{|l|}{ Enzyme activities } \\
\hline $\begin{array}{l}N \text {-Acetyl- } \beta \text {-D-glucosamini- } \\
\text { dase }\end{array}$ & - & - & - & + & + & - & + & + & + & + & + \\
\hline Chymotrypsin & - & - & $\mathrm{w}$ & - & - & $\mathrm{w}$ & - & $\mathrm{w}$ & - & - & - \\
\hline Esterase lipase (C8) & - & - & $\mathrm{w}$ & - & - & - & - & - & - & - & - \\
\hline$\alpha$-Fucosidase & - & - & - & + & + & - & + & + & + & + & + \\
\hline$\alpha$-Galactosidase & + & + & + & + & + & - & + & + & $\mathrm{w}$ & $\mathrm{w}$ & $\mathrm{w}$ \\
\hline$\beta$-Galactosidase & + & + & - & - & + & - & + & $\mathrm{w}$ & + & $\mathrm{w}$ & + \\
\hline$\alpha$-Glucosidase & - & - & + & + & + & + & + & + & + & + & + \\
\hline$\beta$-Glucosidase & $\mathrm{w}$ & $\mathrm{w}$ & + & - & $\mathrm{V}$ & - & - & $\mathrm{w}$ & + & - & - \\
\hline$\alpha$-Mannosidase & - & - & - & $\mathrm{w}$ & - & - & - & $\mathrm{w}$ & - & - & - \\
\hline Major cellular fatty acids & $\begin{array}{c}\text { ai- } C_{15: 0} \\
\mathrm{C}_{18: 1} \omega 9 c \\
\text { i- } \mathrm{C}_{15: 0}\end{array}$ & $\begin{array}{c}\mathrm{C}_{18: 1} \omega 9 c \\
\text { ai- } \mathrm{C}_{15: 0} \\
\text { i- } \mathrm{C}_{15: 0}\end{array}$ & $\begin{array}{c}\mathrm{C}_{16: 0}, \\
\mathrm{C}_{18: 1} \omega 9 c \\
\text { ai- } \mathrm{C}_{15: 0}\end{array}$ & $\begin{array}{c}\mathrm{C}_{18: 1} \omega 9 c \\
\mathrm{i}-\mathrm{C}_{15: 0} \\
\text { ai- } \mathrm{C}_{15: 0}\end{array}$ & $\begin{array}{c}\mathrm{C}_{16: 0} \\
\mathrm{C}_{18: 1} \omega 9 c \\
\text { ai- } \mathrm{C}_{15: 0}\end{array}$ & $\begin{array}{r}\mathrm{C}_{18: 1} \omega 9 c \\
\text { ai- } \mathrm{C}_{15: 0}\end{array}$ & $\begin{array}{r}\mathrm{C}_{18: 1} \omega 9 c \\
\text { ai- } \mathrm{C}_{15: 0}\end{array}$ & $\begin{array}{c}\mathrm{C}_{16: 0}, \mathrm{C}_{18: 1} \omega 9 c \\
\mathrm{C}_{16: 0} \text { 3-OH, ai- } \\
\mathrm{C}_{15: 0}\end{array}$ & $\begin{array}{c}\mathrm{C}_{18: 1} \omega 9 c \\
\mathrm{i}-\mathrm{C}_{17: 0} 3-\mathrm{OH} \\
\text { ai- } \mathrm{C}_{15: 0}\end{array}$ & $\begin{array}{c}\mathrm{C}_{13: 0}, \mathrm{C}_{16: 0} \\
\mathrm{C}_{18: 1} \omega 9 c \\
\mathrm{C}_{16: 0} 3-\mathrm{OH}\end{array}$ & $\begin{array}{r}\mathrm{C}_{18: 1} \omega 9 c \\
\text { ai- } \mathrm{C}_{15: 0}\end{array}$ \\
\hline $\begin{array}{l}\text { Predominant mena- } \\
\text { quinone (s) }\end{array}$ & 10,11 & 10,11 & $11,12,13$ & 12,13 & 10 & 11,12 & 10,11 & 13 & 11,12 & $10,11,12$ & 10,11 \\
\hline DNA G $+C$ content $(\mathrm{mol} \%)$ & 48.1 & 49.0 & $44.2-45.9$ & 48.2 & 46.9 & $51^{a_{\star}}$ & $41.1^{b}$ & $43.1^{c}$ & 41.3 & 44.3 & $42.1^{c}$ \\
\hline
\end{tabular}

${ }^{\star}$ Data taken from: $a$, Downes et al. (2005); b, Sakamoto et al. (2004); c, Watabe et al. (1983). 


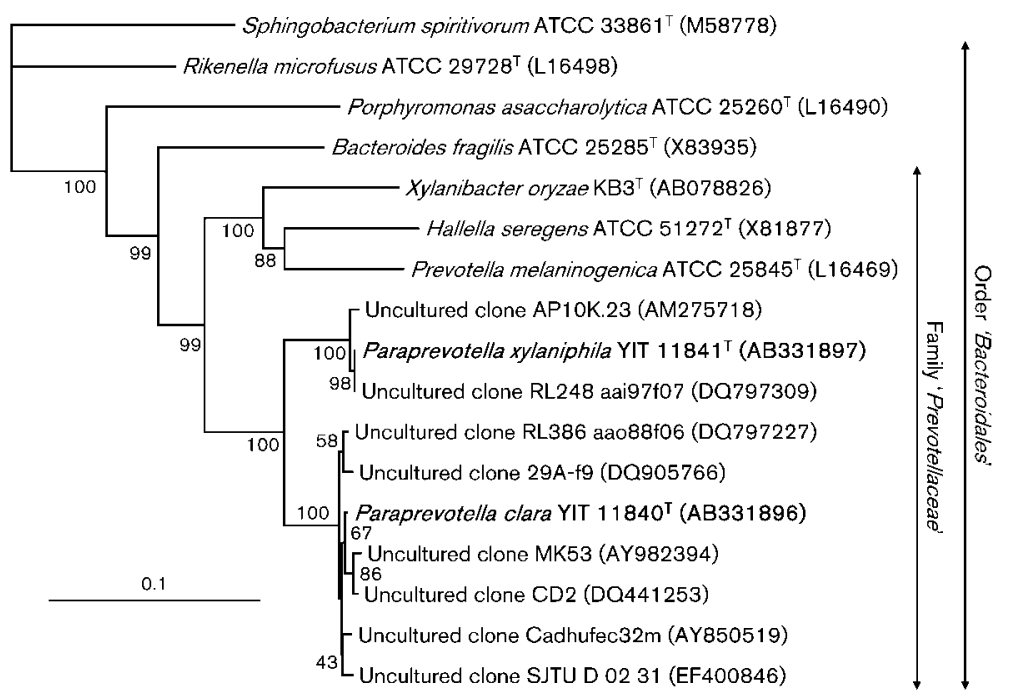

Fig. 1. Neighbour-joining phylogenetic tree, based on 16S rRNA gene sequences, showing the positions of strains YIT $11840^{\top}$ and YIT $11841^{\top}$ and species belonging to the family 'Prevotellaceae'. GenBank/EMBL/DDBJ accession numbers are shown in parentheses. Values shown at branch points are bootstrap percentages (based on 1000 replications). The tree was rooted with Sphingobacterium spiritivorum ATCC $33861^{\top}$. Bar, $10 \%$ sequence divergence.

98.6\%) and YIT $11841^{\mathrm{T}}$ (99.9-99.5\%) were derived from studies of uncultured human faecal or colonic bacteria (Eckburg et al., 2005; Gophna et al., 2006; Mai et al., 2006; Ley et al., 2006; Li et al., 2008; Kassinen et al., 2007) (Fig. 1). These data indicate that these bacteria are common members of the human intestinal microbiota.

Species belonging to the genus Prevotella are common members of the human indigenous intestinal and oral microbiota (for reviews, see Rajilić-Stojanović et al., 2007; Sakamoto et al., 2005). As described above, both the phylogenetic and phenotypic characteristics of strains YIT $11840^{\mathrm{T}}$ and YIT $11841^{\mathrm{T}}$ were similar to those of Prevotella species (Willems \& Collins, 1995). Characteristics that serve to differentiate strains YIT $11840^{\mathrm{T}}$ and YIT $11841^{\mathrm{T}}$ from Prevotella type strains of human oral and intestinal origin are shown in Table 1. On the basis of their phylogenetic distinctiveness, therefore, strains $11840^{\mathrm{T}}$ and $1184 \mathrm{1}^{\mathrm{T}}$ represent two novel species in a novel genus of the family 'Prevotellaceae', for which we propose the names Paraprevotella clara gen. nov., sp. nov. and Paraprevotella xylaniphila sp. nov., respectively.

\section{Description of Paraprevotella gen. nov.}

Paraprevotella (Pa.ra.pre.vo.tel'la. Gr. prep. para beside, next to; N.L. fem. n. Prevotella name of a bacterial genus; N.L. fem. n. Paraprevotella a genus similar to Prevotella).

Cells are Gram-negative, non-spore-forming and nonmotile. Strictly anaerobic. Utilize various sugars and produce succinic and acetic acids as major fermentation end products. The major cellular fatty acids are iso- $C_{15: 0}$, anteiso $C_{15: 0}$ and $\mathrm{C}_{18: 1} \omega 9 \mathrm{c}$. The major respiratory quinones are $\mathrm{MK}-10\left(\mathrm{H}_{0}\right)$ and MK-11 $\left(\mathrm{H}_{0}\right)$. The type species is Paraprevotella clara.

\section{Description of Paraprevotella clara sp. nov.}

Paraprevotella clara (cla'ra. L. fem. adj. clara clear, bright, shining or brilliant, referring to the colony characteristics).
Exhibits the following properties in addition to those given in the genus description. Cells are approximately 0.4$1.3 \times 0.7-2.2 \mu \mathrm{m}$. After 3 days of anaerobic incubation on GAM agar, colonies are $1.5-4.0 \mathrm{~mm}$ in diameter, entire, shiny and translucent with irregular or round margins. Succinic and acetic acids are produced as end products of metabolism from peptone/yeast extract/glucose broth. Positive for acid production from L-arabinose, glucose, lactose, D-mannose, raffinose and D-xylose. Weakly positive for acid production from maltose. Cellobiose, glycerol, Dmannitol, melezitose, L-rhamnose, salicin, D-sorbitol, sucrose and trehalose are not utilized. In the API Rapid ID 32A and API ZYM test systems, positive results are obtained for acid phosphatase, alanine arylamidase, alkaline phosphatase, $\alpha$-arabinosidase, $\alpha$-galactosidase, $\beta$-galactosidase, glutamyl glutamic acid arylamidase and leucyl glycine arylamidase. Negative for $N$-acetyl- $\beta$-glucosaminidase, arginine arylamidase, arginine dihydrolase, chymotrypsin, cystine arylamidase, esterase lipase (C8), esterase (C4), $\alpha$-fucosidase, 6phospho- $\beta$-galactosidase, $\alpha$-glucosidase, $\beta$-glucuronidase, glutamic acid decarboxylase, glycine arylamidase, histidine arylamidase, leucine arylamidase, lipase (C4), $\alpha$-mannosidase, phenylalanine arylamidase, proline arylamidase, pyroglutamic acid arylamidase, serine arylamidase, trypsin, tyrosine arylamidase and valine arylamidase. Weakly positive for $\beta$-glucosidase and naphthol-AS-BI-phosphohydrolase. The DNA G + C content of the type strain is $48.1 \mathrm{~mol} \%$.

The type strain, YIT $11840^{\mathrm{T}}\left(=\mathrm{JCM} 14859^{\mathrm{T}}=\mathrm{DSM}\right.$ $19731^{\mathrm{T}}$ ), was isolated from human faeces.

\section{Description of Paraprevotella xylaniphila sp. nov.}

Paraprevotella xylaniphila (xy.la.ni.phi'la. N.L. n. xylanum xylan; N.L. fem. adj. phila loving; N.L. fem. adj. xylaniphila xylan-loving).

Exhibits the following properties in addition to those given in the genus description. The biological and biochemical 
characteristics of $P$. xylaniphila are very similar to those of $P$. clara, except that there are slight differences with regard to cell size, colony size and acid production from maltose (negative) and D-xylose (weakly positive). Cells are approximately $0.4-1.5 \times 0.9-2.2 \mu \mathrm{m}$. After 3 days of anaerobic incubation on GAM agar, colonies are $0.3-1.0 \mathrm{~mm}$ in diameter, entire, shiny and translucent with irregular or round margins. Succinic and acetic acids are produced as end products of metabolism from peptone/yeast extract/ glucose broth. Positive for acid production from Larabinose, glucose, lactose, D-mannose and raffinose. Weakly positive for acid production from D-xylose. Cellobiose, glycerol, maltose, D-mannitol, melezitose, Lrhamnose, salicin, D-sorbitol, sucrose and trehalose are not utilized. In the API Rapid ID 32A and API ZYM test systems, cells are positive for acid phosphatase, alanine arylamidase, alkaline phosphatase, $\alpha$-arabinosidase, $\alpha$ galactosidase, $\beta$-galactosidase, glutamyl glutamic acid arylamidase and leucyl glycine arylamidase. Negative for $N$-acetyl- $\beta$-glucosaminidase, arginine arylamidase, arginine dihydrolase, chymotrypsin, cystine arylamidase, esterase lipase (C8), esterase (C4), $\alpha$-fucosidase, 6-phospho- $\beta$ galactosidase, $\alpha$-glucosidase, $\beta$-glucuronidase, glutamic acid decarboxylase, glycine arylamidase, histidine arylamidase, leucine arylamidase, lipase (C4), $\alpha$-mannosidase, phenylalanine arylamidase, proline arylamidase, pyroglutamic acid arylamidase, serine arylamidase, trypsin, tyrosine arylamidase and valine arylamidase. Weakly positive for $\beta$-glucosidase and naphthol-AS-BI-phosphohydrolase. The DNA $\mathrm{G}+\mathrm{C}$ content of the type strain is $49.0 \mathrm{~mol} \%$.

The type strain, YIT $11841^{\mathrm{T}}\left(=\mathrm{JCM} 14860^{\mathrm{T}}=\mathrm{DSM}\right.$ $\left.19681^{\mathrm{T}}\right)$, was isolated from human faeces.

\section{Acknowledgements}

We are grateful to Dr Jean P. Euzéby of the École Nationale Vétérinaire de Toulouse (France) for his suggestions regarding the etymology of the species epithets. We thank Dr Haruji Sawada for his understanding and encouragement during our research.

\section{References}

Chonan, O., Matsumoto, K. \& Watanuki, M. (1995). Effect of galactooligosaccharides on calcium absorption and preventing bone loss in ovariectomized rats. Biosci Biotechnol Biochem 59, 236-239.

Chun, J., Lee, J.-H., Jung, Y., Kim, M., Kim, S., Kim, B. K. \& Lim, Y.-W. (2007). EzTaxon: a web-based tool for the identification of prokaryotes based on $16 \mathrm{~S}$ ribosomal RNA gene sequences. Int J Syst Evol Microbiol 57, 2259-2261.

Downes, J., Sutcliffe, I., Tanner, A. C. R. \& Wade, W. G. (2005). Prevotella marshii sp. nov. and Prevotella baroniae sp. nov., isolated from the human oral cavity. Int J Syst Evol Microbiol 55, 1551-1555.

Eckburg, P. B., Bik, E. M., Bernstein, C. N., Purdom, E., Dethlefsen, L., Sargent, M., Gill, S. R., Nelson, K. E. \& Relman, D. A. (2005). Diversity of the human intestinal microbial flora. Science 308, 1635-1638.

Ezaki, T., Saidi, S. M., Liu, S. L., Hashimoto, Y., Yamamoto, H. \& Yabuuchi, E. (1990). Rapid procedure to determine the DNA base composition from small amounts of gram-positive bacteria. FEMS Microbiol Lett 55, 127-130.

Felsenstein, J. (1993). PHYLIP (phylogeny inference package), version 3.5c. Distributed by the author. Department of Genome Sciences, University of Washington, Seattle, USA.

Gophna, U., Sommerfeld, K., Gophna, S., Doolittle, W. F. \& Veldhuyzen van Zanten, S. J. (2006). Differences between tissueassociated intestinal microfloras of patients with Crohn's disease and ulcerative colitis. J Clin Microbiol 44, 4136-4141.

Hayashi, H., Sakamoto, M. \& Benno, Y. (2002). Phylogenetic analysis of the human gut microbiota using $16 \mathrm{~S}$ rDNA clone libraries and strictly anaerobic culture-based methods. Microbiol Immunol 46, 535-548.

Hayashi, H., Shibata, K., Sakamoto, M., Tomita, S. \& Benno, Y. (2007). Prevotella copri sp. nov. and Prevotella stercorea sp. nov., isolated from human faeces. Int J Syst Evol Microbiol 57, 941-946.

Holdeman, L. V., Cato, E. P. \& Moore, W. E. C. (1977). Anaerobe Laboratory Manual, 4th edn. Blacksburg, VA: Virginia Polytechnic Institute and State University.

Kassinen, A., Krogius-Kurikka, L., Mäkivuokko, H., Rinttilä, T., Paulin, L., Corander, J., Malinen, E., Apajalahti, J. \& Palva, A. (2007). The fecal microbiota of irritable bowel syndrome patients differs significantly from that of healthy subjects. Gastroenterology 133, 24-33.

Katsuta, A., Adachi, K., Matsuda, S., Shizuri, Y. \& Kasai, K. (2005). Ferrimonas marina sp. nov. Int J Syst Evol Microbiol 55, 1851-1855.

Komagata, K. \& Suzuki, K. (1987). Lipid and cell-wall analysis in bacterial systematics. Methods Microbiol 19, 161-207.

Kuykendall, L. D., Roy, M. A., O’Neill, J. J. \& Devine, T. E. (1988). Fatty acids, antibiotic resistance, and deoxyribonucleic acid homology groups of Bradyrhizobium japonicum. Int J Syst Bacteriol 38, 358-361.

Ley, R. E., Turnbaugh, P. J., Klein, S. \& Gordon, J. I. (2006). Microbial ecology: human gut microbes associated with obesity. Nature 444, 1022-1023.

Li, M., Wang, B., Zhang, M., Rantalainen, M., Wang, S., Zhou, H., Zhang, Y., Shen, J., Pang, X. \& other authors (2008). Symbiotic gut microbes modulate human metabolic phenotypes. Proc Natl Acad Sci U S A 105, 2117-2122.

Mai, V., Greenwald, B., Morris, J. G., Jr, Raufman, J. P. \& Stine, O. C. (2006). Effect of bowel preparation and colonoscopy on postprocedure intestinal microbiota composition. Gut 55, 1822-1823.

Miller, L. T. (1982). Single derivatization method for routine analysis of bacterial whole-cell fatty acid methyl esters, including hydroxy acids. J Clin Microbiol 16, 584-586.

Morotomi, M., Nagai, F., Sakon, H. \& Tanaka, R. (2008). Dialister succinatiphilus sp. nov. and Barnesiella intestinihominis sp. nov., isolated from human faeces. Int J Syst Evol Microbiol 58, 2716-2720.

Nagai, F., Morotomi, M., Sakon, H. \& Tanaka, R. (2009). Parasutterella excrementihominis gen. nov., sp. nov., a member of the family Alcaligenaceae isolated from human faeces. Int J Syst Evol Microbiol 59, 1793-1797.

Page, R. D. M. (1996). TreeView: an application to display phylogenetic trees on personal computers. Comput Appl Biosci 12, 357-358.

Pearson, W. R. \& Lipman, D. J. (1985). Rapid and sensitive protein similarity searches. Science 227, 1435-1441.

Rajilić-Stojanović, M., Smidt, H. \& de Vos, W. M. (2007). Diversity of the human gastrointestinal tract microbiota revisited. Environ Microbiol 9, 2125-2136.

Saitou, N. \& Nei, M. (1987). The neighbor-joining method: a new method for reconstructing phylogenetic trees. Mol Biol Evol 4, 406425. 
Sakamoto, M., Suzuki, M., Huang, Y., Umeda, M., Ishikawa, I. \& Benno, Y. (2004). Prevotella shahii sp. nov. and Prevotella salivae sp. nov., isolated from the human oral cavity. Int J Syst Evol Microbiol 54, 877-883.

Sakamoto, M., Umeda, M. \& Benno, Y. (2005). Molecular analysis of human oral microbiota. J Periodontal Res 40, 277-285.

Sakon, H., Nagai, F., Morotomi, M. \& Tanaka, R. (2008). Sutterella parvirubra sp. nov. and Megamonas funiformis sp. nov., isolated from human faeces. Int J Syst Evol Microbiol 58, 970975.

Tamura, K., Dudley, J., Nei, M. \& Kumar, S. (2007). MEGA4: molecular evolutionary genetics analysis (MEGA) software version 4.0. Mol Biol Evol 24, 1596-1599.

Thompson, J. D., Gibson, T. J., Plewniak, F., Jeanmougin, F. \& Higgins, D. G. (1997). The CLUSTAL_X windows interface: flexible strategies for multiple sequence alignment aided by quality analysis tools. Nucleic Acids Res 25, 4876-4882.

Wang, X., Heazlewood, S. P., Krause, D. O. \& Florin, T. H. (2003). Molecular characterization of the microbial species that colonize human ileal and colonic mucosa by using $16 \mathrm{~S}$ rDNA sequence analysis. J Appl Microbiol 95, 508-520.

Watabe, J., Benno, Y. \& Mitsuoka, T. (1983). Taxonomic study of Bacteroides oralis and related organisms and proposal of Bacteroides veroralis sp. nov. Int J Syst Bacteriol 33, 57-64.

Willems, A. \& Collins, M. D. (1995). 16S rRNA gene similarities indicate that Hallella seregens (Moore and Moore) and Mitsuokella dentalis (Haapsalo et al.) are genealogically highly related and are members of the genus Prevotella: emended description of the genus Prevotella (Shah and Collins) and description of Prevotella dentalis comb. nov. Int J Syst Bacteriol 45, 832-836. 